\title{
Expression of interferon- $\gamma$ in human adrenal gland and kidney tumours
}

\author{
Q Li',', X-q Zhang', L Nie', G-s Chen', H Li', F Zhang', L-y Zhang', L Hong', S-f Wang' and H Wang ${ }^{3}$ \\ 'State Key Laboratory of Cancer Biology and Department of Pathology, Xijing Hospital, Fourth Military Medical University Xi'an 7I 0032, China; \\ ${ }^{2}$ Department of Medical Biochemistry and Microbiology, Box 582, Biomedical Center, Uppsala S-75I 23, Sweden; ${ }^{3}$ Department of Urinary Surgery, \\ Xijing Hospital, Fourth Military Medical University Xi'an 710032, China
}

It is known that interferon- $\gamma$ (IFN- $\gamma$ ) is produced by activated T and NK lymphoid cells, mononuclear cells, and macrophage and dendritic cells. Our previous studies have shown that IFN- $\gamma$-like immunoreactivity also appears in human adrenal cortical tumour and phaeochromocytoma. To investigate whether human tumour cells can produce IFN- $\gamma$, we examined 429 biopsy specimens of 30 kinds of tumour and tumour-surrounding tissues in adrenal glands and in kidneys by using immunohistochemistry and in situ hybridisation. IFN- $\gamma$ immunoactivity was shown in 34.3\% of the adrenal cortical adenomas, $50 \%$ of the adrenal cortical carcinomas, $26.7 \%$ of the phaeochromocytomas, $26.7 \%$ of the clear cell renal cell carcinomas (RCCs), $22 \%$ of the adrenal cortexes and $40 \%$ of medullas adjacent to tumours. The positive samples and expression areas were well overlapped between the IFN- $\gamma$ mRNA and the immunohistochemistry staining. Western blot analysis has further confirmed the immunohistochemistry results by showing a distinct IFN- $\gamma$ band corresponding to $17.4 \mathrm{kDa}$ in tissue extracts from adrenal cortical adenoma, phaeochromocytoma and clear cell RCCs. These results indicate that IFN- $\gamma$ is produced by some types of tumour cells, suggesting it may play a dual role in the development of these tumours.

British Journal of Cancer (2007) 97, 420-425. doi:I0.I038/sj.bjc.6603870 www.bjcancer.com

Published online 10 July 2007

(c) 2007 Cancer Research UK

Keywords: interferon- $\gamma$; adrenal tumour; clear cell renal cell carcinoma

Interferon- $\gamma($ IFN- $\gamma)$ is a multi-functional cytokine produced mainly by macrophages, dendritic cells, activated T lymphocytes and NK cells (Tripp et al, 1993; Gessani and Belardelli, 1998; Fukao et al, 2000; Murphy et al, 2000). In addition to its well-known antiviral activities, IFN- $\gamma$ also plays a role in host antitumor responses. Endogenously produced IFN- $\gamma$ is reported to function in cancer immunosurveillance, protecting the host against the growth of transplanted tumours and the formation of primary, chemically induced spontaneous tumours (Shankaran et al, 2001; Street et al, 2001). Mice deficiency of IFN- $\gamma$ signalling developing spontaneous tumours at a higher frequency than normal mice further indicates that IFN- $\gamma$ is involved in immune response to tumours (Kaplan et al, 1998). IFN- $\gamma$ also regulates cell proliferation and apoptosis via activating the downstream JAK-STAT signalling pathway (Buard et al, 1998; Haque and Williams, 1998; WeberNordt et al, 1998; Lee et al, 2000). IFN- $\gamma$-like immunoreactivity has been proved to appear in human adrenal cortical tumours, phaeochromocytomas and hepatocellular carcinomas (HCCs) by immunohistochemical method (Li and Song, 1995, 1996; Chia et al, 2002). However, immunohistochemistry analysis alone cannot confirm whether tumour cells produce IFN- $\gamma$. To answer this question, we used immunohistochemistry combined with in situ hybridisation and Western blot method to screen a cluster of different types of tumours.

*Correspondence: Dr Q Li; E-mail: liqing@fmmu.edu.cn Revised I 5 March 2007; accepted 5 June 2007; published online 10 July 2007

\section{MATERIALS AND METHODS}

\section{Biopsy material}

A total of 429 biopsy specimens of 30 kinds of tumour and three types of tumour-surrounding tissues were collected from patients who had not received any chemotherapeutic or immunomodulatory treatment before operations. Tumour tissues were classified according to the classification system of the World Health Organization (Table 1). Tissue specimens were fixed for $18-24 \mathrm{~h}$ in $10 \%$ buffered formalin and routinely processed to paraffin embedding.

\section{Immunohistochemistry}

Serial sections from each case were stained with a mouse monoclonal antibody specific to human IFN- $\gamma$ (United States Patent 4599306, Department of Immunology, Fourth Military Medical University, Xi'an, China). This antibody has optimised specificity by using the method of microwave antigen retrieval on formalin-fixed, paraffin-embedded tissue. Immunohistochemical staining was performed using a standard streptavidin-biotinperoxidase complex (SABC) (BOSTER Incorporation, Wuhan, China). Visualisation was performed using diaminobenzidine (DAB) for the horseradish peroxidase. The sections were counterstained with haematoxylin, dehydrated and mounted. A positive control was performed using the L26 (anti-CD20) monoclonal antibody (Dako, Glostrup, Denmark) a marker of B lymphocytes. 


\begin{tabular}{|c|c|c|c|c|c|}
\hline \multirow[b]{2}{*}{ Histopathological diagnosis } & \multirow[b]{2}{*}{ Total case number } & \multirow[b]{2}{*}{ Male } & \multirow[b]{2}{*}{ Female } & \multicolumn{2}{|c|}{ Age } \\
\hline & & & & Median & Range \\
\hline Tumour around adrenal cortex & 9 & 6 & 3 & 43 & $28-56$ \\
\hline Tumour around adrenal medulla & 5 & 4 & । & 41 & $26-48$ \\
\hline Adrenal cortical adenoma & 35 & 21 & 14 & 45 & $28-64$ \\
\hline Adrenal cortical carcinoma & 4 & 4 & 0 & 49 & $35-57$ \\
\hline Phaeochromocytoma & 30 & 17 & 13 & 41 & $12-48$ \\
\hline Tumour around kidney & 23 & 19 & 4 & 54 & $51-68$ \\
\hline Clear cell RCC & 60 & 47 & 13 & 56 & $42-73$ \\
\hline Hemangioma & 10 & 4 & 6 & 21 & $12-36$ \\
\hline Fibroadenoma of breast & 10 & 0 & 10 & 49 & $35-59$ \\
\hline Ovarian teratoma & 10 & 0 & 10 & 29 & $19-36$ \\
\hline Leiomyoma & 10 & 0 & 10 & 43 & $26-56$ \\
\hline Pituitary adenoma & 10 & 0 & 10 & 38 & $32-47$ \\
\hline Thyroid adenoma & 10 & 2 & 8 & 36 & $21-43$ \\
\hline Intestinal adenoma & 10 & 7 & 3 & 29 & $16-49$ \\
\hline Ovarian adenoma & 10 & 0 & 10 & 23 & $|8-3|$ \\
\hline Cutaneous papilloma & 10 & 6 & 4 & 32 & $16-46$ \\
\hline Gastric carcinoma & 10 & 6 & 4 & 52 & $38-73$ \\
\hline Intestinal carcinoma & 10 & 7 & 3 & 47 & $29-69$ \\
\hline Breast carcinoma & 10 & 8 & 2 & 56 & $39-76$ \\
\hline Thyroid carcinoma & 10 & 3 & 7 & 43 & $34-58$ \\
\hline Pancreatic carcinoma & 10 & 7 & 3 & 56 & $43-74$ \\
\hline Bladder carcinoma & 10 & 10 & 0 & 63 & $4 \mid-78$ \\
\hline Larynx squamous carcinoma & 10 & 10 & 0 & 51 & $35-67$ \\
\hline Squamous carcinoma of skin & 10 & 4 & 6 & 47 & $44-63$ \\
\hline Cervical squamous carcinoma & 10 & 0 & 10 & 54 & $41-69$ \\
\hline Nasopharyngeal carcinoma & 10 & 9 & । & 46 & $32-58$ \\
\hline Lung cancer & 10 & 6 & 4 & 62 & $24-84$ \\
\hline Meningeoma & 10 & 6 & 4 & 32 & $14-37$ \\
\hline Astrocytoma & 10 & 7 & 3 & 48 & $16-70$ \\
\hline Rhabdomyosarcoma & 10 & 7 & 3 & 12 & $6-48$ \\
\hline Osteosarcoma & 10 & 10 & 0 & 19 & $14-33$ \\
\hline Fibrosarcoma & 10 & 5 & 5 & 16 & $17-42$ \\
\hline Hepatocellular carcinoma & 10 & 4 & 6 & 43 & $34-51$ \\
\hline
\end{tabular}

RCC, renal cell carcinomas.

Negative controls were obtained by replacing the primary antibody with non-immune mouse serum.

\section{Immunoblotting}

Fresh tissue samples from six cases of adrenal cortical adenomas, five cases of phaeochromocytomas, five cases of clear cell renal cell carcinomas (RCCs) and one case of colonic adenocarcinoma were cut into small pieces and homogenised using a Polytrope highspeed metal homogeniser (Brinkmann Instruments, Westbury, NY, USA) in five volumes of $50 \mathrm{mmoll}^{-1}$ Tris buffer ( $\mathrm{pH} \quad 7.7$ ) containing $0.5 \mathrm{mmoll}^{-1}$ phenylmethylsulphonylfluoride to inhibit proteolysis. The supernatant was obtained after centrifugation at 12000 r.p.m. min $^{-1}$ for $15 \mathrm{~min}$ at $4^{\circ} \mathrm{C}$. A volume of $1 \mu \mathrm{l}$ supernatant from each sample was dot blotted on a polyvinylidene fluoride (PVDF) paper. Immunostaining was performed using a standard SABC (BOSTER Incorporation). Negative control was obtained by replacing the primary antibody with non-immune mouse serum.

\section{Sodium dodecyl sulfate-polyacrylamide gel electrophoresis and Western blot analysis}

The dot blotting positive samples (two from adenomas, one from phaeochromocytoma and one from clear cell RCCs) and one negative colonic carcinoma were separated by $15 \%$ SDSpolyacrylamide gels (PAGE). Molecular weight markers (C-6210; Sigma Chemical Co, St Louis, MO, USA) were run together with the samples. After the separation, the proteins were electroblotted onto
PVDF paper utilising the Phast system. The PVDF membranes were blocked by incubation in $0.02 \mathrm{moll}^{-1} \mathrm{Na}_{2} \mathrm{HPO}_{4}, 0.15 \mathrm{moll}^{-1}$ $\mathrm{NaCl}, \mathrm{pH} 7.2$ containing $0.05 \%$ Tween 20 and $3 \%$ bovine serum albumin for $1 \mathrm{~h}$ at room temperature and then followed by immunoblotting. Negative control was obtained by replacing the primary antibody with non-immune mouse serum.

\section{In situ hybridisation analysis}

In situ hybridisation for IFN- $\gamma$ mRNA was performed on further serial sections from 35 cases of adrenal cortical adenomas, four cases of adrenal cortical carcinomas, 30 cases of phaeochromocytomas, 60 cases of clear cell RCCs, 10 cases of HCCs, nine cases of tumour surrounding adrenal cortexes, five cases of medullas and 23 cases of tumour around renal tissues by using an oligonucleartide IFN- $\gamma$ kit (BOSTER Incorporation). The experiment was performed according to the instruction. Briefly, after de-waxing and re-hydration, sections were pretreated with $0.3 \%$ hydrogen peroxide to suppress the endogenous peroxide. Tissues were postfixed with $1 \%$ paraformaldehyde and were further reacted with prehybridisation solution. A volume of $30 \mu \mathrm{l}$ hybridisation solution was supplied on each tissue section with glass coverslips and incubated overnight at $38-42^{\circ} \mathrm{C}$. Coverslips were removed and the sections were washed. After blocking solutions, the sections were incubated with biotinilated mouse-anti-digoxingin for $1 \mathrm{~h}$ at $37^{\circ} \mathrm{C}$. The sections were then washed thoroughly and incubated with $\mathrm{SABC}$ at room temperature. Visualisation was performed by using DAB. The sections were counterstained with haematoxylin, then dehydrated and mounted. 
Controls were processed with the omission of the probe and with mRNase before hybridisation.

\section{Scoring of immunohistochemistry and in situ hybridisation}

The immunoreactivity and in situ hybridisation were scored according to the staining extension and intensity. The intensity of staining was scored from 0 to 3: 0 for negative; 1 for weak; 2 for moderate; 3 for strong staining. The extension of immunoreactivity was estimated from 0 to 4 : 0 for negative; 1 for $1-25 \%$; 2 for $26-50 \%$; 3 for $51-75 \%$; 4 for $76-100 \%$ of positive immunoreactivity cells. The positive immunoreactivity or in situ hybridisation staining was determined by the combined staining score (intensity score plus extent score): 0 for $\leqslant 2 ; 1$ for $3 ; 2$ for $4-5 ; 3$ for $6-7$.

\section{RESULTS}

\section{Immunohistochemistry}

The immunoreactive IFN- $\gamma$-positive cells displayed distinct brown staining; immunoreactive materials appearing as densely packed granules in the entire or focal of cytoplasm, whereas immunostaining was undetectable in negative control sections, indicating that IFN- $\gamma$ immunoreactive staining was specific.

Prominent staining cells for immunoreactive IFN- $\gamma$ was observed in 12 out of 35 (34.3\%) of the adrenal cortical adenomas, two of four $(50 \%)$ of the adrenal cortical carcinomas, eight out of $30(26.7 \%)$ of the phaeochromocytomas and 16 out of $60(26.7 \%)$ of the clear cell RCC. The IFN- $\gamma$ immunoreactivity was mainly restricted to tumour cells, and was also in some lymph cells and macrophages but was usually not in other non-tumour cells. The IFN- $\gamma$ immunoreactivity was also demonstrated in two out of nine $(22 \%)$ of the adrenal cortex and two out of five $(40 \%)$ of the medulla tissues adjacent to tumours (Figures 1 and 2 and Table 2).
However, IFN- $\gamma$ immunoreactivity could not be detected in renal tissues surrounding clear cell RCCs. Surprisingly, the rest 260 tumour biopsies, originating from other organs than adrenal gland and kidney, did not show IFN- $\gamma$ immunostaining in any single case.

\section{Western blot analysis}

A distinct IFN- $\gamma$ band corresponding to $17.4 \mathrm{kDa}$ (Figure 3) was observed in tissue extracts from two out of six cases of the adrenal cortical adenomas, one out of five cases of the phaeochromocytomas and one out of five cases of the clear cell RCCs. Colonic adenocarcinoma and negative control did not show positive staining.

\section{In situ hybridisation analysis}

IFN- $\gamma$ mRNA signals could only be seen in the sections reacted with antisense probe. It has no staining in control sections, which either have omitted IFN- $\gamma$ probe or have prior incubated with mRNase. Prominent cytoplasmic staining for IFN- $\gamma$ mRNA were detected in 13 out of 35 of the adrenal cortical adenomas, two out of four of the cortical carcinomas, nine out of 30 of the phaeochromocytomas, 16 out of 60 of the clear cell RCC, two out of nine of the tumour adjacent tissues in adrenal cortexes and two out of five of the medullas. No IFN- $\gamma$ mRNA was detected in the renal tissues surrounding clear cell RCC. The IFN- $\gamma$ expressing samples and areas were well overlapped in between of mRNA signal and immunohistochemistry staining (Figure 2).

\section{DISCUSSION}

The adrenal gland consists of two distinct types of primary tumours: one arising from the adrenal cortex, including adenomas and carcinomas, and the other from the medulla representing neural crest-derived chromaffin cell tumours

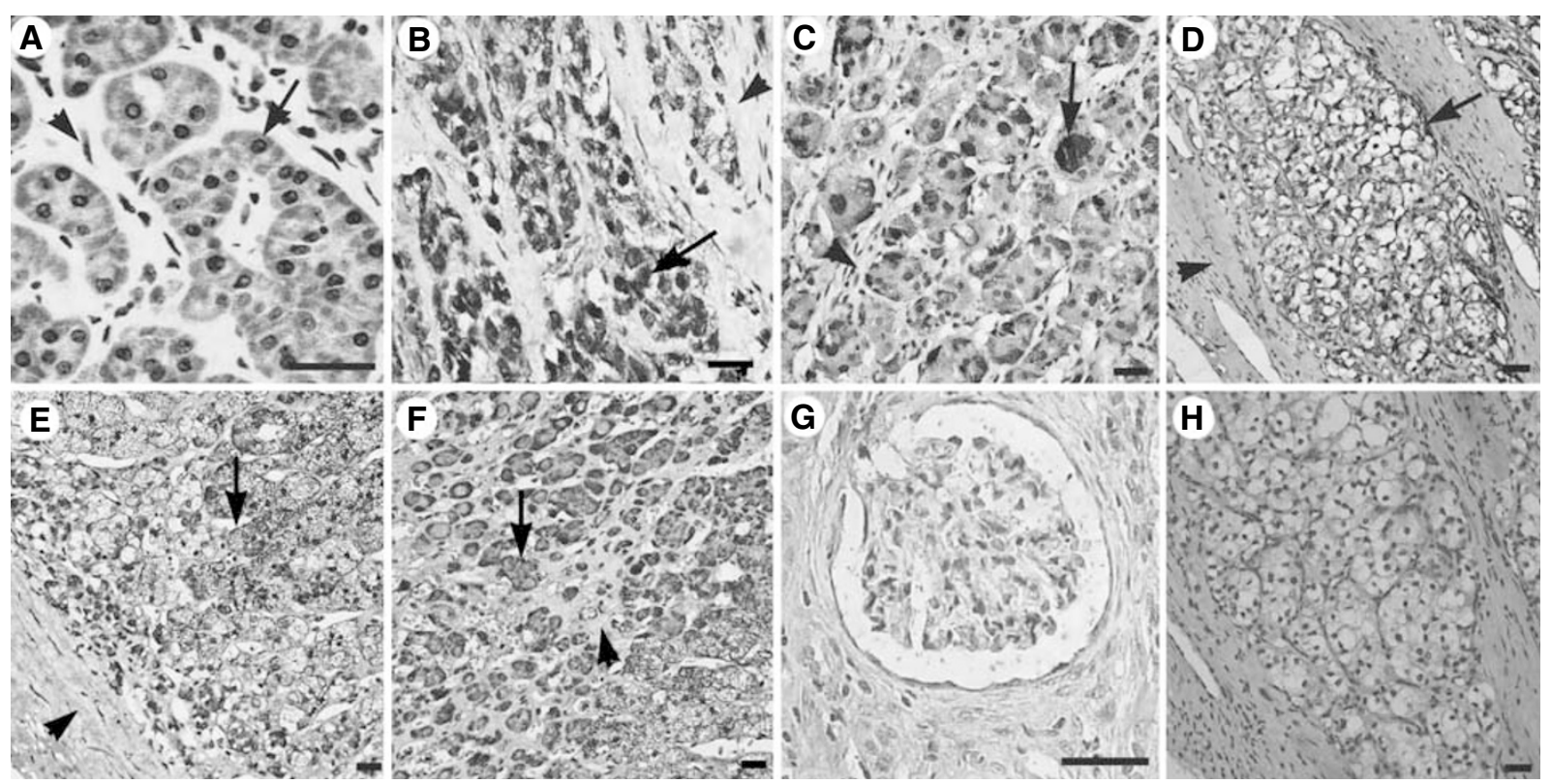

Figure I IFN- $\gamma$ immunoreactivity in (A) adrenal cortical adenoma, (B) cortical carcinoma, (C) phaeochromocytoma, (D) clear cell RCC, tumour adjacent tissue in $(\mathbf{E})$ adrenal cortex $(\mathbf{F})$ and medulla. The immunoreactive IFN- $\gamma$-positive cells show distinct brown staining. The immunoreactive materials often appear as densely packed granules filling the entire or focal of cytoplasm of tumour cells (arrow) and the interstitial tissue is negative (arrowhead). No IFN- $\gamma$ immunoreactivity is seen in (G) kidney. Clear cell RCC (same case as in $\mathbf{D}$ ) matched $(\mathbf{H})$ negative control staining do not show any positive staining. Bar $=50 \mu \mathrm{m}$. 


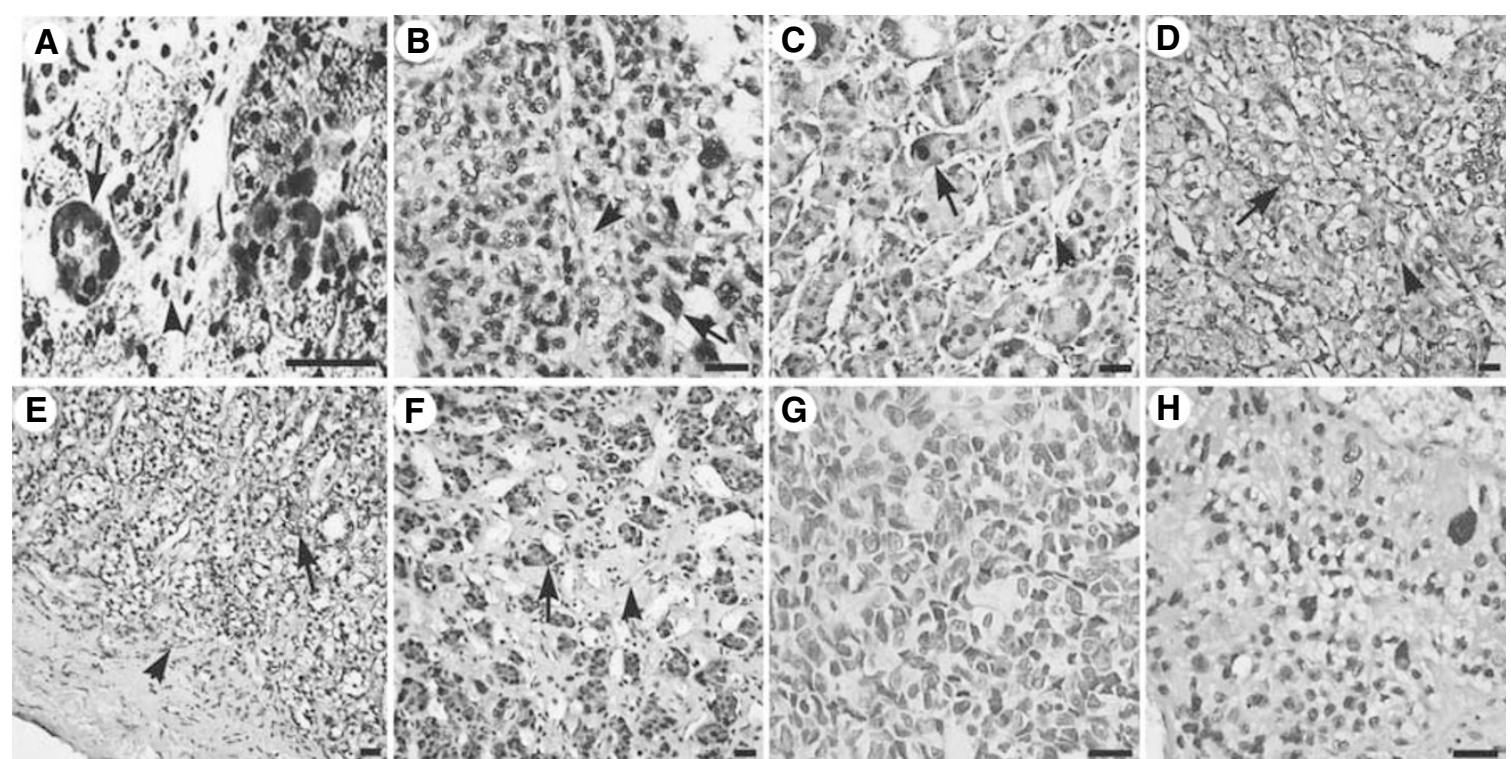

Figure 2 In situ hybridisation for IFN- $\gamma$ mRNA. The IFN- $\gamma$ mRNA signals are seen in adrenal (A) cortical adenoma, (B) cortical carcinoma, (C) phaeochromocytoma, (D) clear cell RCC, tumour adjacent tissue $(\mathbf{E})$ in adrenal cortex $(\mathbf{F})$ and medulla. IFN- $\gamma$ mRNA is apparent in the cytoplasm of parenchyma cells (arrow), not in interstitial tissue (arrowhead). IFN- $\gamma$ mRNA signals are not seen in HCC (G). Adrenal cortical carcinoma (same case as in B) matched negative control with $(\mathbf{H})$ mRNase do not show any positive staining. Bar $=50 \mu \mathrm{m}$.

Table 2 IFN- $\gamma$ immunoreactivity in tumours and tumours adjacent tissues

\begin{tabular}{lcrlllcr}
\hline & & \multicolumn{7}{c}{ Score } & & \\
\cline { 3 - 6 } Type & Case no. & $\mathbf{0}$ & $\mathbf{~}$ & $\mathbf{2}$ & $\mathbf{3}$ & Positive no. & $\%$ \\
\hline ACA & 35 & 23 & 2 & 7 & 3 & 12 & 34.3 \\
ACC & 4 & 2 & 0 & 0 & 2 & 2 & 50.0 \\
Phaeo & 30 & 22 & 0 & 4 & 4 & 8 & 26.7 \\
CRCC & 60 & 44 & 5 & 8 & 3 & 16 & 26.7 \\
TAC & 9 & 7 & 0 & 0 & 2 & 2 & 22.2 \\
TAM & 5 & 3 & 0 & 1 & 1 & 2 & 40.0 \\
\hline
\end{tabular}

$\mathrm{AC}$, tumour around adrenal cortex; $\mathrm{ACA}$, adrenal cortical adenoma; $\mathrm{ACC}$, adrenal cortical carcinoma; Phaeo, phaeochromocytoma; CRCC, clear cell renal cell carcinoma; IFN- $\gamma$, interferon- $\gamma$; TAM, tumour around adrenal medulla.

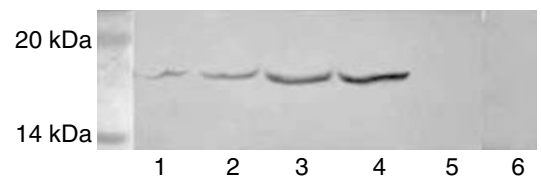

Figure 3 Western blot analysis for IFN- $\gamma$. A $17.4 \mathrm{kDa}$ IFN- $\gamma$ protein band appears in the extracts from adrenal cortical adenomas (lanes I and 2), clear cell RCC (lane 3) and pheochromocytoma (lane 4). Negative control (lane 5, same case as in lane I) and colonic adenocarcinoma (lane 6) do not show any band.

(pheaochromocytomas). RCC is a group of malignancies arising from the epithelium of the renal tubules. Clear cell RCC, one type of RCC, is composed of cells with clear or eosinophilic cytoplasm within a delicate vascular network.

Our previous study has demonstrated that IFN- $\gamma$-like immunoreactivity appeared in the cytoplasm of tumour cells in adrenal cortical adenoma, cortical carcinoma and pheochoromocytoma by using DB1 monoclonal antibody (Li and Song, 1995, 1996). The
IFN- $\gamma$-like immunoreactivity is not a non-specific binding, since no staining was detected in the absence of primary antibody. In addition, DB1 monoclonal antibody is a high-affinity antibody against rat IFN- $\gamma$ with specific labelling of different molecular forms of recombinant rat IFN- $\gamma$, inhibiting biological effects of IFN- $\gamma$ in vitro and in vivo (Jacob et al, 1987; van der Meide et al, 1986). However, DB1 is a monoclonal antibody against rat IFN- $\gamma$ but not human IFN- $\gamma$. In the present study, a monoclonal mouseanti-human IFN- $\gamma$ antibody was used to characterise the IFN- $\gamma$ immunoactivity in 429 human biopsy samples from 30 different types of tumours and tumour-surrounding tissues in adrenal glands and in kidneys. The results showed that $34.3 \%$ of the adrenal cortical adenomas, $50 \%$ of the adrenal cortical carcinomas, $26.7 \%$ of the phaeochromocytomas and $26.7 \%$ of the clear cell RCC expressed IFN- $\gamma$ immunoactivity. IFN- $\gamma$ was not detectable in other types of tumour. Western blot analysis revealed IFN- $\gamma$ band corresponding to $17.4 \mathrm{kDa}$ in tissue extracts from two out of six cases of the adrenal cortical adenomas, one out of five cases of the phaeochromocytomas and one out of five cases of the clear cell RCCs, whereas the colonic adenocarcinoma and the negative control did not show any band. The results suggest that the IFN- $\gamma$ immunoactivity is specific.

To confirm that the IFN- $\gamma$ is indeed produced in tumour cells, IFN- $\gamma$ mRNA in situ hybridisation was performed on the same biopsy samples. The in situ hybridisation results confirmed our hypothesis that the transcripts of IFN- $\gamma$ genes were inside the adrenal and RCC tumour cells. The mRNA expressing tissues were overlapped with the immunohistochemistry staining, indicating that the IFN- $\gamma$ protein was generated by tumour cells. IFN- $\gamma$ protein and mRNA levels were generally higher in adrenal cortical adenomas than in cortical carcinomas. Clear cell RCCs expressed both mRNA and IFN- $\gamma$ protein, but not in the tumour-surrounding renal tissue. Therefore, IFN- $\gamma$ expression may in some way correlated to the tumour malignancy level or cell differentiation.

It remains unclear why IFN- $\gamma$ was expressed in $22 \%$ of tumour surrounding tissue in adrenal cortexes and $40 \%$ of in medullas. Cells with IFN- $\gamma$-like immunoreactivity have also been reported in type II alveolar epithelial cells in interstitial lung disease (Wallace and Howie, 1999), rat neurons (Kiefer et al, 1991), rat skeletal 
muscle (Nennesmo et al, 1989), transplanted rat heart tissue (Wanders et al, 1992), astrocytes in active chronic multiple sclerosis lesion (Traugott and Lebon, 1988) and cerebrovascular endothelial cells from aged mice (Wei et al, 2000). However, there was no further report about the significance of the IFN- $\gamma$ expression in those tissues or cells. IFN- $\gamma$ has also been reported weakly expressed in HCCs (Chia et al, 2002). But in the present study, neither protein nor mRNA of IFN- $\gamma$ was expressed in the 10 cases of HCCs, probably because that the methods we used are not sensitive enough.

It is well known that IFN- $\gamma$ contributes to the increased antitumour activity of immune cells, though the reason why some tumour cells produce IFN- $\gamma$ is not clear. Previous studies have established that testicular germ cell tumour cells can express both mRNA and protein of IFN- $\gamma$ and the expressed IFN- $\gamma$ is able to induce the chemokine IP-10, indicating its biological activity, whereas it is not able to phosphorylate the downstream STAT1 (Schweyer et al, 2002, 2003). A number of tumours and tumour cell lines have also been reported to develop a permanent and selective IFN- $\gamma$ insensitivity, such as testicular germ cell tumours, RCC cell line, basal cell carcinoma of the skin and human lung adenocarcinoma cell lines (Kooy et al, 1998; Dovhey et al, 2000; Nagao et al, 2000; Schweyer et al, 2002, 2003; Dunn et al, 2005b). Such insensitivity to IFN- $\gamma$ is due to lack of expression of IFN- $\gamma$ receptors or the receptor downstream genes. Tumour cells can naturally develop mutations on IFN- $\gamma$ downstream target genes, such as JAK and Stat1, to render them insensitive to IFN- $\gamma$.

Recently, a concept of cancer immunoediting has been put forward (Ikeda et al, 2002; Dunn et al, 2004a, b, 2005a, b, 2006). It is a process consisting of three phases: elimination (i.e., cancer immunosurveillance), equilibrium and escape. The immune

\section{REFERENCES}

Buard A, Vivo C, Monnet I, Boutin C, Pilatte Y, Jaurand MC (1998) Human malignant mesothelioma cell growth: activation of janus kinase 2 and signal transducer and activator of transcription 1alpha for inhibition by interferon-gamma. Cancer Res 58: $840-847$

Chia CS, Ban K, Ithnin H, Singh H, Krishnan R, Mokhtar S, Malihan N, Seow HF (2002) Expression of interleukin-18, interferon-gamma and interleukin-10 in HCC. Immunol Lett 84: 163-172

Dovhey SE, Ghosh NS, Wright KL (2000) Loss of interferon-gamma inducibility of TAP1 and LMP2 in a renal cell carcinoma cell line. Cancer Res 60: 789-796

Dunn GP, Bruce AT, Sheehan KC, Shankaran V, Uppaluri R, Bui JD, Diamond MS, Koebel CM, Arthur C, White JM, Schreiber RD (2005a) A critical function for type I interferons in cancer immunoediting. Nat Immunol 6: $722-729$

Dunn GP, Koebel CM, Schreiber RD (2006) Interferons, immunity and cancer immunoediting. Nat Rev Immunol 6: 836-848

Dunn GP, Old LJ, Schreiber RD (2004a) The immunobiology of cancer immunosurveillance and immunoediting. Immunity 21: 137-148

Dunn GP, Old LJ, Schreiber RD (2004b) The three Es of cancer immunoediting. Annu Rev Immunol 22: 329-360

Dunn GP, Sheehan KC, Old LJ, Schreiber RD (2005b) IFN unresponsiveness in LNCaP cells due to the lack of JAK1 gene expression. Cancer Res 65: $3447-3453$

Fukao T, Matsuda S, Koyasu S (2000) Synergistic effects of IL-4 and IL-18 on IL-12-dependent IFN- $\gamma$ production by dendritic cells. J Immunol 164: $64-71$

Gessani S, Belardelli F (1998) IFN- $\gamma$ expression in macrophages and its possible biological significance. Cytokine Growth Factor Rev 9: 117-123

Haque SJ, Williams BR (1998) Signal transduction in the interferon system. Semin Oncol 25: 14-22

Ikeda H, Old LJ, Schreiber RD (2002) The roles of IFN gamma in protection against tumour development and cancer immunoediting. Cytokine Growth Factor Rev 13: 95-109

Jacob OO, Van der Meide PH, McDevitt HO (1987) In vivo treatment of $(\mathrm{NAB}+\mathrm{NZW}) \mathrm{F}$ lupus-like nephritis with monoclonal antibody to $\gamma$ interferon. J Exp Med 166: 798-803 system not only protects the host against development of primary nonviral cancers but also sculpts tumour immunogenicity. Thus, IFN- $\gamma$ may play a dual role in preventing development of primary and transplanted tumours on one hand, and sculpting the immunogenic phenotype of tumours on the other. Tumour escape may be attributable to tumour genetic changes that affect tumour recognition by immune effective cells (such as, loss of antigen expression, loss of MHC components, shedding of NKG2D ligands and development of IFN- $\gamma$ insensitivity) or provide tumours with mechanisms to escape immune destruction (such as, defects in death-receptor signalling pathways or expression of antiapoptotic signals including constitutively active STAT3). The dysregulation of MHC class I processing and presentation, or/and development of IFN- $\gamma$ insensitivity in tumour cells, would allow tumours to escape from the elimination phase of the cancer immunoediting process (Dunn et al, 2004b). However, whether the specific expression of IFN- $\gamma$ in tumours from adrenal gland and kidney is correlated with tumour escape is not clear and needs to be further elucidated.

In conclusion, we provide solid evidence that tumour cells express IFN- $\gamma$ protein and mRNA especially in adrenal gland and kidney tumours. Our findings give a further insight into the role of IFN- $\gamma$ in the pathogenesis of tumour, which will be critical for effective immunotherapeutic approaches for cancer therapy in the future.

\section{ACKNOWLEDGEMENTS}

The present work was supported by grants from the Chinese Army Medical Research Council (02ma04).
Kaplan DH, Shankaran V, Dighe AS, Stockert E, Aguet M, Old LJ, Schreiber RD (1998) Demonstration of an interferon gamma-dependent tumour surveillance system in immunocompetent mice. Proc Natl Acad Sci USA 95: $7556-7561$

Kiefer R, Haas CA, Kreutzberg GW (1991) Gamma interferon-like immunoreactive material in rat neurons: evidence against a close relationship to gamma interferon. Neuroscience 45: 551-560

Kooy AJ, Tank B, Vuzevski VD, van Joost T, Prens EP (1998) Expression of interferon-gamma receptors and interferon-gamma-induced up-regulation of intercellular adhesion molecule-1 in basal cell carcinoma; decreased expression of IFN-gamma R and shedding of ICAM-1 as a means to escape immune surveillance. J Pathol 184: 169-176

Lee CK, Smith E, Gimeno R, Gertner R, Levy DE (2000) STAT1 affects lymphocyte survival and proliferation partially independent of its role downstream of IFN-gamma. I Immunol 164: 1286-1292

Li Q, Song J (1995) Gamma interferon-like immunoreactivity in adrenal gland and cortical tumour. Zhonghua Binglixue Zazhi 24: 372-374

Li Q, Song J (1996) Expression of gamma interferon-like substance in adrenal pheochromocytoma. Zhonghuan Ne fen mi Za zhi 12: 90-92

Murphy KM, Ouyang W, Farrar JD, Yang J, Ranganath S, Asnagli H, Afkarian M, Murphy TL (2000) Signaling and transcription in T helper development. Annu Rev Immuno 18: 451-494

Nagao M, Nakajima Y, Kanehiro H, Hisanaga M, Aomatsu Y, Ko S, Tatekawa Y, Ikeda N, Kanokogi H, Urizono Y, Kobayashi T, Shibaji T, Kanamura T, Ogawa S, Nakano H (2000) The impact of interferon gamma receptor expression on the mechanism of escape from host immune surveillance in HCC. Hepatology 32: 491-500

Nennesmo I, Olsson T, Ljungdahl A, Kristensson K, Van der Meide PH (1989) Interferon-gamma-like immunoreactivity and T-cell marker expression in rat skeletal muscle fibres. Brain Rev 504: 306-310

Schweyer S, Soruri A, Baumhoer D, Peters J, Cattaruzza M, Radzun HJ, Fayyazi A (2002) Expression of CXC chemokine IP-10 in testicular germ cell tumours. J Pathol 197: 89-97

Schweyer S, Soruri A, Peters J, Wagner A, Radzun HJ, Fayyazi A (2003) A Malignant germ cell tumours of the testis express interferon-gamma, but are resistant to endogenous interferon-gamma. Br J Cancer 89: 915-921 
Expression of IFN- $\gamma$ in human adrenal gland and kidney tumours Q Li et al

Shankaran V, Ikeda H, Bruce AT, White JM, Swanson PE, Old LJ, Schreiber RD (2001) IFN gamma and lymphocytes prevent primary tumour development and shape tumour immunogenicity. Nature 410: 1107-1111

Street SE, Cretney E, Smyth MJ (2001) Perforin and interferon-gamma activities independently control tumour initiation, growth, and metastasis. Blood 97: $192-197$

Traugott U, Lebon PJ (1988) Interferon-gamma and Ia antigen are present on astroctes in active chronic multiple sclerosis lesion. J Neurol Sci 84: $257-264$

Tripp CS, Wolf SF, Unanue ER (1993) Interleukin-12 and tumour necrosis factor are costimulators of interferon- $\gamma$ production by natural killer cells in severe combined immuno-deficiency mice with listeriosis, and interleukin10 is a physiologic ntagonist. Proc Natl Acad Sci USA 90: 3725-3729

van der Meide PH, Borman AH, Beljaars HG, Dubbeld MA, Botman CA, Schellekens H (1986) The purification and characterization of rat gamma interferon by use of two monoclonal antibodies. I Gen Virol 67: $1059-1071$

Wallace WA, Howie SE (1999) Immunoreactive interleukin 4 and interferon-gamma expression by type II alveolar epithelial cells in interstitial lung disease. J Pathol 187: 475-480

Wanders A, Wells AF, Larsson E, Tufveson G, Olsson T, Ljungdahl A, Klareskog L (1992) Expression of an interferon-gamma-like substance in normal and transplanted rat heart tissue. J Heart Lung Transpl 11: $142-146$

Weber-Nordt RM, Mertelsmann R, Finke J (1998) The JAK - STAT pathway: signal transduction involved in proliferation, differentiation and transformation. Leuk Lymphoma 28: 459-467

Wei YP, Kita M, Shinmura K, Yan XQ, Fukuyama R, Fushiki S, Imanishi J (2000) Expression of IFN-gamma in cerebrovascular endothelial cells from aged mice. J Interferon Cytokine Res 20: 403-409 